\title{
Ohjaamisen mahdollisuudesta
}

ppija, oppiminen, jopa opettaja ovat sallittua aikuiskasvatuksen sanastoa. Opettaminen ei ole. Opettamisella on aikuiskasvatuksessa imago-ongelma samalla tavoin kuin lasten- ja nuortenkasvatuksessa kasvatuksella. Kasvatukselle on annettu ajasta riippuen erilaisia selittäviä etumerkkejä, kuten vapaan kasvatuksen vaihtoehdoksi ohjaava kasvatus - vaikka muitakin kuin lapsikeskeisiä tulkintoja ohjaavasta kasvatuksesta on. Käsitteet tulevat ja

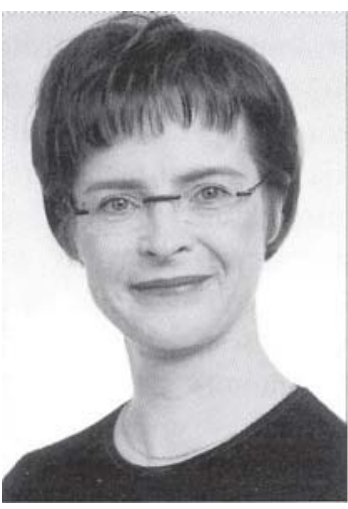

kurssiputken imuun.

Seminaarin esityksissä tuotiin myös esille, että ohjaus on kriittinen käsite. Aikuisten ohjaus nousee paljolti kahdenkeskisestä keskustelun ja kohtaamisen perinteestä, jossa erityisesti ohjaajan tulisi olla tietoinen tilanteessa tuotetusta kielestä ja vallasta. Kriittistä katsetta voidaan laajentaa ohjaustilanteen ulkopuolelle ja kysyä, miksi ohjausta on järjestetty. Pitkäaikaistyöttömien työllistämiseksi? Pia Silvennoisen menevät. Yhtä poissa kuin "opettaminen” on myös ohjauksen vastinpari "itseohjautuvuus", joka vielä vuosikymmen sitten oli aikuisen oppimisen luovuttamaton tunnuspiirre. Tieto- ja viestintäteknologian kehityksen nähtiin antavan itseohjautuvuudelle hyvät edellytykset, mutta sittemmin juuri tätä tulkintaa on kritisoitu, myös Aikuiskasvatus-lehdessä. On huomattu, että vaativat teknologisesti välittyneet oppimisympäristöt edellyttävät kehittynyttä ohjausta ja vieläpä aivan uudenlaista käsitystä ohjauksesta. Ohjausvuorovaikutuksen sijaan huomion keskiöön on tullut ohjauksen suunnittelu, teknologiapohjainen design. Tässä mielessä Saara Repo-Kaarennon viime vuonna ilmestynyt kirja "Innostu ryhmästä Miten ohjata oppivaa yhteisöä" on kirjaimellisesti raikas tuulahdus aikuiskoulutuksen parhaasta perinteestä. Se jättää teknologian tarjoamat välineet sivuun ja asettaa ohjaavan opettajan itsensä välineeksi oppivan yhteisön käyttöön. Saaran kirja antoi aiheen joulukuussa pidetylle seminaarille 'Ohjaaminen oppijan tukena', jota pohtimaan kutsuttiin opettajia, aikuiskouluttajia, tutkijoita ja opiskelijoita.

Oppimisen ohjaaminen ilmentää sitä, että opettaja ei ole se, joka tietää ja opettaa tietonsa oppijalle, vaan oppija itse sosiaalisessa oppimistapahtumassa hankkii ja reflektoi tietoa. Aikuisten opettajan tehtävä on ohjata tätä tapahtumaa. Ohjaajan taitoa on nivoa yksilön oppimistavoitteet ryhmän tavoitteisiin, huolehtia siitä, että ryhmän dynamiikka toimii ja dialogisuus toteutuu. "Innostu ryhmästä” rohkaisee meitä aikuiskouluttajia laittamaan itsemme likoon ja jatkamaan horjuviakin toisin tekemisen kokeilujamme antautumatta tutkimassa työvoimapoliittisessa koulutuksessa ohjauksesta tuli myös sukupolvi- ja sukupuolikysymys. Ohjauksen piilo-opetussuunnitelmaan sisältyvä itseohjautuvuuden periaate ei välttämättä avaudu ihmiselle, jonka koulunkäyntikokemukset juontavat vuosikymmenien taa. Refleksiikaista Annaa, Teijaa ja Riittaa pohtimaan uusia elämänsuuntia, mutta jättävät Matin ja Jounin mykäksi. Jussi Silvonen toi esille sen, että ohjauksen osin ei-tarkoitettuja. Tulosten näkeminen edellyttää aikaperspektiiviä ja ohjauksen tarkastelua ohjattavien kasvun ja kehityksen haasteiden valossa, lähikehityksen vyöhykkeellä, sanoisi joku.

Ohjaus pelkkänä vuorovaikutussuhteena on tyhjä käsite. Harri Kukkosen mukaan ohjauksessa käsiteltävä sisältö laskeutuu ohjaajan ja ohjattavan väliin yhdessä rakennettavaksi kohteeksi. Ohjaustilanne on itsensä asemointia toiseen ja sisältöön eivätkä ohjauksen kysymykset tällöin olisikaan ensi sijassa didaktisia, vaan eettisiä, epistemologisia ja ontologisia. Ohjaamisen etiikkaa pohti Jussi Onnismaa seminaarin päätteeksi. Jos ohjausvuorovaikutuksessa todellisuutta tuotetaan moniäänisten, useita aikatasoja tavoittavien kertomusten avulla, ohjaamisen etiikka rakentuu tilanteisesti, sisältä päin pikemmin kuin ulkoa annetuista abstrakteista normistoista käsin. Olkoon siis jokainen oman ohjauksensa seppä.

\section{Hanna Toiviainen}

Kirjoittaja on Aikuiskasvatuksen Tutkimusseuran johtokunnan jäsen. Tutkimusseuran ajankohtaisista asioista lisää tässä numerossa sivuilla 24 ja 72. visyyden ja avautumisen periaatteet saattavat rohvaikutukset ovat monimutkaisesti eriytyneitä ja 